Swarthmore College

Works

4-1-2015

\title{
Using Volunteer Mentors To Improve The Academic Outcomes Of Underserved Students: The Role Of Relationships
}

Amanda Bayer

Swarthmore College, abayer1@swarthmore.edu

J. B. Grossman

D. L. DuBois

Follow this and additional works at: https://works.swarthmore.edu/fac-economics

Part of the Economics Commons

Let us know how access to these works benefits you

\section{Recommended Citation}

Amanda Bayer, J. B. Grossman, and D. L. DuBois. (2015). "Using Volunteer Mentors To Improve The Academic Outcomes Of Underserved Students: The Role Of Relationships". Journal Of Community Psychology. Volume 43, Issue 4. 408-429. DOI: 10.1002/jcop.21693

https://works.swarthmore.edu/fac-economics/329

This work is brought to you for free by Swarthmore College Libraries' Works. It has been accepted for inclusion in Economics Faculty Works by an authorized administrator of Works. For more information, please contact myworks@swarthmore.edu. 
PREPRINT_Journal of Community Psychology 43(4): 408-429, April 2015.

Using Volunteer Mentors to Improve the Academic Outcomes of Underserved Students:

The Role of Relationships

\author{
Amanda Bayer \\ Swarthmore College \\ Jean Baldwin Grossman \\ Princeton University and MDRC
}

David L. DuBois

University of Illinois at Chicago

Amanda Bayer, Department of Economics, Swarthmore College

Jean Grossman, Woodrow Wilson School, Princeton University, and MDRC

David DuBois, Institute for Health Research and Policy, University of Illinois at Chicago

We are grateful to the organizations that funded and supported the original evaluation providing the data for the present study, including The Atlantic Philanthropies, Philip Morris USA, and The William T. Grant Foundation, The Edna McConnell Clark Foundation, and Big Brothers Big Sisters of America. We also thank Lynn Conell-Price for research assistance and Carla Herrera for her support and wisdom.

Address correspondence to: Amanda Bayer, Department of Economics, Swarthmore College, 500 College Avenue, Swarthmore, PA 19081.E-mail: abayer1@swarthmore.edu 
Using Volunteer Mentors to Improve the Academic Outcomes of Underserved Students:

The Role of Relationships

\begin{abstract}
Schools can benefit from understanding how to use community volunteers to achieve academic goals. A randomized control evaluation, involving 1139 students from 71 schools, of the school-based mentoring program of Big Brothers Big Sisters of America found modest but statistically significant improvements in the teacher-rated academic performance and self-reported scholastic efficacy of mentored students. The present study explores the causal mechanism behind these effects. We find that a close relationship between mentor and protégé appears key to better academic outcomes. Because relationship closeness is not randomly assigned, we use two-stage least squares and other methods to control for potential selection bias. The role of emotional closeness as a mediator of program effects is evident across mentoring relationships of various lengths and statuses. Students were more likely to feel close to their mentors in programs that included weekly meetings and opportunities for mentor-protégé pairs to interact outside of a large-group setting.

Keywords: School-Based Mentoring, Relationships, Academic, Volunteers
\end{abstract}


Financially distressed school districts need to identify low-cost ways to support struggling students in struggling schools. School-based mentoring (SBM) programs, in which volunteers meet regularly with students on school grounds, are an increasingly popular option. As of 2005, the last date for which data are available, SBM was the fastest-growing form of mentoring in the United States, with 870,000 adults mentoring children in schools as part of one formal program or another (MENTOR, 2006).

The mission of SBM programs such as those offered by Big Brothers Big Sisters of America (BBBSA) is to "provide children facing adversity with ... one-to-one relationships that change their lives for the better" (BBBSA, 2013c). Even though based in schools, the primary objective of the mentoring program is to provide a friend, not a tutor, as illustrated by the following description from the organization's website:

Although it takes place at schools, our School-Based Mentoring program isn't limited to the classroom. Of course, some Littles do talk with their Bigs about class, or do homework, or read together, but it's perfectly fine to shoot hoops in the gym or play on the playground. At the end of the day, it's really all about starting a friendship, providing guidance and inspiring them to reach their potential. (BBBSA, 2013b)

Prior research on mentoring relationships outside of school (for example, DuBois \& Neville, 1997; Parra et al., 2002; Thomas \& Zand, 2010; Zand et al., 2009) suggests that feelings of closeness and related indicators of the emotional quality of the mentor-protégé tie are important mediators of the effect of mentoring on youth outcomes. To date there has not been a rigorous test of the role of relationship closeness in promoting academic outcomes through SBM. Does SBM work primarily through the connection that the protégé feels with the volunteer mentor rather than through other, more direct processes, such as engaging the child in academic activities during meetings? The present research addresses this question using data from a randomized trial evaluation of the BBBSA SBM program conducted by Public/Private Ventures (P/PV). Because of course relationship closeness cannot be randomly assigned, we use instrumental variables and other controls to account for preexisting characteristics of protégés that may influence both closeness and outcomes. We also investigate the characteristics of programs, mentors, and protégés that may increase the likelihood of a close mentor-protégé relationship. We present findings that may help practitioners design SBM programs more conducive to close relationships and perhaps, in turn, to more favorable academic results. 
Mentoring, broadly conceptualized, is a youth development intervention that seeks to provide a child with an additional caring adult relationship (DuBois \& Karcher, 2014). Mentoring programs typically pair children with volunteer adults or older students and facilitate regular meetings of the pairs, with the expectation that the child benefits from the additional adult support and guidance. Similar to many programs, BBBSA's programs target children in risky circumstances, including "children living in single parent homes, growing up in poverty, and coping with parental incarceration” (BBBSA, 2013a).

In the school-based form of mentoring, adults or older students meet with their protégés on school grounds during the school day or immediately after, typically for one hour per week during the academic year. BBBSA began partnering with schools over fifteen years ago to extend the reach of its successful communitybased mentoring (CBM) services. Although BBBSA screens, trains, and supervises mentors in both types of programs, the contact and context of SBM is more constrained than in CBM, which typically involves longer meetings and locations and activities that the pairs plan and choose themselves. The more limited time commitment and firmer structure of SBM make it easier for agencies to recruit volunteers. And because protégé referrals to SBM programs come from teachers and school personnel rather than being dependent on parental initiative as in CBM, SBM also reaches groups of children who would not otherwise be served (Herrera, 2004). Although there are other providers of SBM, BBBSA is the largest in the United States. It alone administered 126,000 school-based matches in 2006 (Herrera et al., 2007).

Available evidence on the effectiveness of SBM is encouraging, though somewhat mixed. The P/PV random assignment impact evaluation of the BBBSA program found that, relative to controls, students who were assigned to receive mentoring showed small but statistically significant improvements in several academic outcomes, including teacher-rated academic performance and student-reported feelings of scholastic efficacy (Herrera et al., 2007; Herrera et al., 2011). On the other hand, a randomized control evaluation of SBM programs funded by the U.S. Department of Education's Student Mentoring Program did not find significant effects on academic outcomes (Bernstein et al., 2009). Wheeler, Keller, and DuBois (2010, p.14) note that the findings of this latter evaluation "may have been attenuated by a range of factors such as the absence of a welldelineated program model, a lack of additional implementation support for study agencies, and a relatively 
high percentage of the children in the intervention group who were never paired with a mentor."

In contrast, the BBBSA SBM program has well-defined national standards. These include, for example, an expectation that mentors receive monthly support contacts from program staff, which research suggests is important for establishing high-quality mentoring relationships (Herrera, DuBois, \& Grossman, 2013).

Agencies participating in the $\mathrm{P} / \mathrm{PV}$ evaluation were required to have at least four years of experience delivering SBM, strong agency leadership, and strong, established relationships with participating schools (Herrera et al., 2007). Moreover, in this evaluation only 7 percent of the children in the intervention group were never matched with a mentor, less than half the rate in the U.S. Department of Education study. For these reasons, the data from the $\mathrm{P} / \mathrm{PV}$ evaluation offer an especially rigorous and informative basis for examining mechanisms underlying the effects of SBM. Furthermore, agencies involved in this trial had the opportunity to vary potentially consequential aspects of program practice, including the extent to which academics were a focus during mentoring meetings. We exploit this variation to explore whether some program practices are more or less conducive to close relationships between protégés and mentors.

Theoretical models developed in the context of CBM programs suggest that the critical component of mentoring is the relationship that develops between the child and the mentor (Ferguson \& Snipes, 1994; Rhodes, 2005). Such models typically assume that if a supportive adult consistently spends time with a child, the pair can form an emotionally close and mutually trusting relationship. The child can thus develop socially, emotionally, and cognitively and think more positively about herself (Harter, 1990; Ferguson \& Snipes, 1994), ultimately leading to better outcomes in areas such as academics. Available research (see DuBois et al., 2011 and Rhodes, 2005) supports the assumption that relationship quality, including feelings of closeness specifically, does have an important influence on youth outcomes. Most of this research, however, has been on mentoring outside of school. There are several reasons its conclusions do not automatically generalize to SBM. For example, mentor-protégé interactions are limited in time and context in SBM, and relationships tend to be shorter than in CBM programs. SBM relationships may not have a chance to reach the levels of closeness or emotional connection needed to promote better academic outcomes (by, for example, radiating effects on the protégé's relationships with teachers and parents). 
Prior research with CBM programs has supported the hypothesis that mentoring relationships and their effects grow stronger over time (Grossman \& Rhodes, 2002). In their investigation using data from the P/PV SBM study, Grossman et al. (2012) found little evidence that impacts on academic outcomes varied with the length of time a protégé was matched with a mentor, but they do find effects of match status. Relative to controls, protégés in intact mentoring relationships showed significant improvement on teacher-rated academic performance. On the other hand, those who had been rematched with a new mentor after an initial match ended did significantly worse than the controls. These negative effects were not apparent for protégés whose initial mentoring relationships had ended but who had not been rematched. As we investigate whether relationship closeness is the key ingredient to an effective SBM experience, we take care to distinguish the effects of closeness from the potentially confounding effects of both match length and match status.

Cavell and Elledge (2014) challenge the assumption that a good relationship is a precondition for positive youth outcomes in mentoring programs, which they refer to as the "mentoring-as-relationship" perspective. They argue that mentoring also may be influential because it provides a context for activities or experiences that serve specific goals, such as the development of improved academic skills. From this alternative "mentoring-as-context" perspective, they note that benefits to protégés would accrue independent of their mentoring relationships' strength. Because SBM programs are based in schools, and because some SBM programs specifically emphasize academic activities, mentoring-as-context mechanisms could account for the academic benefits of program participation. The present investigation is thus well suited to inform the debate on this important, unresolved issue of the relative importance of relational mechanisms to effective mentoring.

\section{METHOD}

\section{Study Design and Sample}

The sample for our study consists of the students who participated in the randomized control trial of the BBBSA SBM program, conducted during the 2004-2005 school year (Herrera et al., 2007). Study participants were recruited by 10 BBBSA study agencies across the country, each with four or more years of experience in SBM. Recruitment proceeded in the usual way, that is, mostly through referrals by school staff; children had to be entering grades four through nine and had to have parental consent to be part of the research. 
Over one thousand $(1,139)$ students across 71 public schools in rural and urban school districts $(41$ elementary, 27 middle, and 3 high schools) met these criteria. After completing a baseline survey, half (565) of the students were randomly assigned by researchers to the treatment group to be matched with a mentor and the other half (574) were placed on a waiting list to be matched 15 months later, at the end of the study. Randomization was stratified by school. The students' teachers and mentors also completed baseline surveys in the fall of 2004 . Follow-up surveying of all groups occurred at the end of the school year, beginning in April 2005. Data from a second follow-up survey in the fall of 2005 are not analyzed due to a high level of attrition over the summer.

Table 1 reports basic descriptive statistics for the control and treatment samples at baseline. Overall, just over half (54 percent) of the students were female and the majority ( 63 percent) were members of ethnic and racial minority groups. Most (69 percent) received free or reduced-price lunches, and students reported experiencing an average of four stressful events, such as moving or parents separating, in the six months prior to the baseline survey. On average they struggled academically, receiving below a 3.0 on the teacher-rated outcome measures (the rating for "average" or "satisfactory" performance). The average age was 11. There were no statistically significant differences between the control group and the group assigned to treatment.

All but 6 percent of the protégés completed the survey at follow up. Survey completion rates were slightly lower for teachers, with follow-up outcome measures missing for approximately 16 percent of the overall sample. Importantly, however, survey noncompletion rates are almost identical for the treatment and control groups ( 6 percent versus 7 percent for the student survey, and 16 percent versus 17 percent for the teacher survey). According to evidence standards developed and used by the What Works Clearinghouse of the U.S. Department of Education's Institute of Education Sciences (2011), this combination of overall and differential attrition should yield an acceptable level of bias even under conservative assumptions.

\section{Program Overview}

About half (49 percent) of SBM programs had protégés meet their mentors only during the school day, with the others meeting after school (47 percent) or both during and after school (4 percent). Programs reported using a variety of locations in the school for meetings, including the cafeteria (41 percent), library (34 percent), and a designated classroom (33 percent). Some programs used more than one meeting place. Almost 
half of all mentoring pairs shared their meeting space with other pairs.

According to mentor reports, pairs engaged in a wide variety of activities, and most were chosen by protégé and mentor together ( 49 percent) or by the protégé alone (20 percent). For example, mentors reported doing each of the following types of activities "a lot": talking casually (71 percent), talking about family or friends ( 43 percent and 44 percent, respectively), talking about the future ( 30 percent), playing indoor games (54 percent), doing creative activities ( 36 percent), playing sports ( 25 percent), doing homework (27 percent), and talking about academic issues (31 percent). Many pairs met for between 45 and 60 minutes ( 40 percent) but another 39 percent met for more than an hour. Almost all matches met three (10 percent) or four (79 percent) times a month. Over the year, the average protégé received 17 hours of mentoring over 5.3 months.

Mentors were predominately female ( 72 percent). Three-quarters ( 77 percent) of the mentors were white, and nearly half (48 percent) were high school students. On average, mentors reported receiving 45 minutes of training before first meeting their protégés. The BBBSA agencies overseeing the school programs had an average of 9.5 years of experience implementing SBM. BBBSA supported sites during implementation through meetings and teleconferences. Table 2 presents statistics summarizing program features in this study.

\section{Outcome Measures and Key Variables}

This study examines changes in four academic measures, each measured at baseline and at the end of the school year for each student. Higher scores indicate better outcomes. Overall academic performance is a rating by the student's teacher of the student's performance on a single-item, five-point scale from 1 = "below grade level” to 5 = “excellent” (Pierce, Hamm, \& Vandell, 1999). Pierce, Bolt, and Vandell (2010) report correlations in the $.60 \mathrm{~s}$ between such teacher ratings and standardized achievement test scores. Quality of work is a three-item scale score calculated as a mean of teacher ratings of the correctness, neatness, and completeness of a child's classwork on a five-point scale from 1 = "well below average" to 5 = "well above average" (Herrera, 2004; coefficient alpha values of .88 at baseline and .90 at follow-up). Completion of schoolwork is a two-item average of the teacher's rating of the number of in-class and homework assignments the student completed in the last four weeks on a five-point scale ranging from $1=$ "well below average" to $5=$ "well above average" (Herrera, 2004; alpha values of .93 at baseline and .94 at follow-up). Scholastic efficacy beliefs 
is the average across six items of a student's ratings of his or her own ability to do schoolwork on a four-point scale from 1 = "not at all true" to 4 = "very true." Items include "I do very well at my class work" and reverse coding of "I often forget what I learn" (Harter, 1985; alpha values of .70 at baseline and .72 at follow-up).

Four explanatory variables are central to our exploration of the mechanism of SBM. Following Herrera et al. (2007), relationship closeness is a single-item measure recording protégé responses to the question "How close do you feel to your mentor?" on a four-point scale where 1 = "not close at all," 2 = "not very close," 3 = "somewhat close," and 4 = "very close." The question, part of the follow-up survey at the end of the school year, instructs students to rate their current or most recent mentor. Preliminary analyses (available upon request) indicated a threshold measure of closeness, which records whether the relationship was at least "somewhat close," performs as well as the four-response measure. Tests of equality restrictions found that mentoring experiences receiving either of the two lower closeness ratings produced statistically similar impacts on academic outcomes, as did mentoring experiences receiving either of the two higher ratings (e.g., for overall academic performance, $\mathrm{F}(2,937)=0.00, \mathrm{p}=.9992)$. Accordingly, the analyses reported in this paper use a dichotomous measure to represent relationships as close (rating of "somewhat" or "very" close) or not ("not close at all" or "not very close").

Match length is the total number of weeks of a protégé's current or most recent mentoring match at the time of the follow-up survey, corresponding to the relationship for which we have closeness ratings. While Grossman et al. (2012) defined match length as the total days of mentoring across all of a student's matches, we define match length slightly differently given our focus on the relationship between two particular individuals. We record whether match duration was short (lasting less than 12 weeks), medium (between 12 and 24 weeks), or long (more than 24 weeks). Match status is the status of the protégé's original mentoring match at the end of the school year. The original mentoring match was "intact," or that match ended and the student experienced a "rematch" with a new mentor, or it ended and the student was given "no rematch" with a new mentor. Teacher relationship is the average across 11 items of a student's ratings of teacher connectedness (Karcher, 2003) and teacher relationship quality. Items are rated on a four-point scale from $1=$ "not at all true" to 4 = "very true" and include "I always try hard to earn my teachers' trust" and a reverse coding of "My 
teachers don't know me very well this year" (alpha value of .82 at baseline and at follow-up). We use the baseline value of this variable as a measure of the child's ability to have a close relationship with a nonparental adult. Herrera et al. (2007) provides additional detail on the outcome measures and other variables.

\section{Analysis Plan}

Regression specifications in which the outcome, $\mathrm{Y}_{\mathrm{i}}$, is regressed on the assigned treatment indicator, $\mathrm{Z}_{\mathrm{i}}$, provide unbiased estimates of the average impact of SBM across all protégés. Consider:

$$
\mathrm{Y}_{\mathrm{i}}=\alpha_{1}+\beta_{\mathrm{ITT}} \mathrm{Z}_{\mathrm{i}}+\mathrm{X}_{\mathrm{i}} \gamma_{1}+\varepsilon_{1 \mathrm{i}}
$$

where $\mathrm{X}_{\mathrm{i}}$ is a vector of covariates, which in our analyses is the pretreatment value of the outcome, and $\varepsilon_{\mathrm{i}}$ is the unexplained variation in outcomes. These intention-to-treat (ITT) estimates, $\beta_{\mathrm{ITT}}$, help inform us about the average effectiveness of the programs as currently configured.

$\beta_{\text {ITT }}$ provides a fairly good estimate of the impact of meeting with a mentor, since only 7 percent of the treatment students were never matched. But because only 75 percent of the students assigned to treatment rated their relationship with their mentor as "somewhat close" or "very close," it does not represent the impact of providing a child with a close, caring relationship with a nonparental adult, widely viewed as the essence of mentoring. The randomized assignment, $Z_{\mathrm{i}}$, merely influences the probability that a student in the mentoring group receives the treatment of interest, $T_{i}$, where $T_{i}$ represents a close mentor-protégé relationship. To understand the effect of such relationships, that is, the effect among the "compliers" with the SBM treatments à la Angrist, Imbens, and Rubin (1996), we regress outcomes on the receipt of the intended treatment, $\mathrm{T}_{\mathrm{i}}$, and derive the treatment-on-treated (TOT) estimates, $\beta_{\text {TOT. }}$.

$$
\mathrm{Y}_{\mathrm{i}}=\alpha_{2}+\beta_{\mathrm{TOT}} \mathrm{T}_{\mathrm{i}}+\mathrm{X}_{\mathrm{i}} \gamma_{2}+\varepsilon_{2 \mathrm{i}}
$$

An unbiased estimate of $\beta_{\text {Tот }}$ indicates the impact of SBM when it is operating as designed, providing children with close relationships with program mentors. We must take care not to reintroduce selection bias into the results. Although treatment status, $\mathrm{Z}_{\mathrm{i}}$, was assigned randomly, the students who received the intended treatment, $\mathrm{T}_{\mathrm{i}}$, are not necessarily a random subset. These students may have an underlying characteristic that affects both the likelihood that they experience a close relationship with a mentor and their academic progress over the study year, such as a general ability to form good relationships with adults. One approach is to control 
for the characteristic explicitly. We include the teacher relationship variable in our ordinary least squares (OLS) regressions as a measure of a student's ability, $\mathrm{A}_{\mathrm{i}}$, to have a close relationship with a nonparental adult.

Alternatively, when compliance is imperfect, we can use the randomized treatment status, $\mathrm{Z}_{\mathrm{i}}$, as an instrument for the treatment of interest, having a close relationship with a mentor, $\mathrm{T}_{\mathrm{i}}$. As established in Angrist et al. (1996), random assignment status is an ideal candidate for an instrument because it is independent of student characteristics. In our analyses, $Z_{i}$ proves to be a strong instrument for $T_{i}(F=1956, p=0.0)$, allowing us to produce two-stage least squares (2SLS) estimates of the impact of program participation on those protégés who successfully connected with their assigned mentors (Bloom, 1984; Imbens \& Angrist, 1994).

The instrumental variables estimate can be interpreted as the average treatment effect for students who experience a close relationship with a program mentor under two assumptions, monotonicity and independence (Angrist et al., 1996). Monotonicity requires that the assignment of a mentor increase the likelihood of a new close mentoring relationship for each and every student assigned to treatment. This requirement is met, because control students were not offered the opportunity to form relationships with BBBSA mentors. Independence requires that we be able to identify the causal impact of the instrument, which is also true by construction here, and that potential outcomes not be directly affected by the instrument. This exclusion restriction requires that having a close relationship with one's mentor completely mediates all effects of assignment to SBM on academic outcomes. We explore the validity of this assumption empirically.

Assignment to the mentoring group, which is our instrument $Z_{\mathrm{i}}$, may affect students who do not form close relationships if, say, SBM yields academic benefits as a result of the time those students spend working on homework and other academic activities with mentors. We thus propose and test a competing hypothesis to that which presumes the centrality of relationships: namely, that protégés' academic outcomes are affected by the time spent on academic activities in match meetings, whether or not the mentor-protégé relationship is a close one. Although most SBM programs in this data set devote little meeting time to academics, 225 of 565 treatment students were in programs that reported spending more than 25 percent of their meeting time on academic activities such as homework help and tutoring. We define such programs to be "academically focused," in contrast to the other, "relationship-only" programs. This variation in program focus allows us to 
test the validity of the exclusion assumption in our instrumental variable analyses. It also allows us to explore the effects of treatment in the two program types relative to the control group and relative to each other.

\section{RESULTS}

\section{The Occurrence of Close Relationships in SBM}

Many of the SBM matches were "successes," in that protégés characterized them as close. Of the 565 students assigned to treatment, 75.4 percent rated their relationships with their mentors as somewhat or very close at the time of the follow-up survey. The remaining 24.6 percent of treatment students were either never matched or rated their relationship as "not close at all" or "not very close."

Figure 1 reports the proportion of students who described their relationships with their mentors as somewhat or very close, by duration in months. A majority of matches of any duration are rated favorably by the protégés. After three months of meetings, over four-fifths of relationships are close, and that proportion does not increase appreciably with match duration — suggesting that most matches that ever achieved some degree of a close emotional connection did so within three months.

\section{Impact of Relationship Closeness on Academic Outcomes}

Table 3 presents the impact coefficients and associated standard errors for each of the four academic outcome measures. Estimates reported as statistically significant in the table remain significant at a target level of significance of .05 after correcting for multiple comparisons (Benjamini \& Hochberg, 1995). Column (1) contains estimates from the intention-to-treat specification presented in equation (1). Consistent with the findings reported by Herrera et al. (2007), we find that students who were assigned to receive mentoring show statistically significant improvements in their academic outcomes. Column (2) presents the potentially biased but straightforward treatment-on-treated estimates from OLS regression of outcomes on the treatment $\mathrm{T}_{\mathrm{i}}, \mathrm{a}$ close mentor-protégé relationship, as in equation (2). The estimates in column (2) are about 20 percent larger than those in column (1), as would be expected under the incomplete compliance with treatment, and indicate that a relationship rated as somewhat or very close by the protégé is associated with better academic outcomes.

Some children are better at working with adults, and these children may have both better mentoring relationships and better school performance. Column (3) addresses the potential omitted variable problem by 
including in our OLS specifications the teacher relationship variable to control directly for the possible confounding factor. This variable has a positive and statistically significant association with academic outcomes in the data set (details available upon request). Notably, comparing columns (2) and (3), including the teacher relationship variable does not affect the estimated impact of a close mentoring relationship. Column (4) shows the results using instrumental variable methods. The estimated effects of a close mentor-protégé relationship in the 2SLS model are at least as large as the OLS estimates presented in column (2) and indicate statistically significant academic benefits associated with a close mentoring relationship.

Effect sizes, obtained by dividing the impact coefficients reported in the table by the appropriate standard deviations, range from 0.13 (for overall academic performance and scholastic efficacy beliefs) to 0.18 (for completeness of schoolwork) and are consistent across alternative specifications. The similarity in the estimates across columns (2) through (4) suggest that there may not be an omitted variable bias issue in the OLS specifications in column (2), removing the need for instrumental variable techniques in follow-up analyses. Heteroskedasticity-robust Hausman (1978) tests of endogeneity do not reject the null hypothesis that relationship closeness is exogenous, and the OLS specifications appear to provide unbiased estimates of the impact of providing a child with a close, caring relationship with a program mentor.

Table 4 provides further indication that these estimates can be interpreted as the causal effect of a close mentoring relationship. These OLS regressions add a variable indicating the presence of a mentoring relationship that is "not close at all" or "not very close." If the effects of "assigned a mentor but did not receive treatment (did not have a close relationship)" were statistically significant, we might conclude that SBM enhances student academic performance through alternative pathways. Instead, we find no evidence that mentoring enhances academic performance when the protégé does not feel close to the mentor.

The specifications in Table 5 are like those in columns (1) and (4) of Table 3, but they also include an indicator variable specifying whether a student was at a site that ran an academically focused program and two treatment dummies, one indicating students assigned to treatment at an academically focused site and one indicating students assigned to treatment at a relationship-only site. In columns (1) and (3), we constrain the impacts across these two types of sites to be the same, whereas in columns (2) and (4) we allow them to differ 
and test whether the constraint is valid. The first two columns of Table 5 present intention-to-treat estimates for the constrained and unconstrained specifications. In general, assignment to the treatment group appears to have similar effects whether the mentoring occurs with an academic focus or not; the estimated effects are not significantly different across program types for any of the four outcome measures, although the data may not have sufficient power to distinguish the effects of the two types of programs.

The next two columns of Table 5 investigate possible program differences in treatment effects on the treated, though we do not expect a different verdict given the similar rates of relationship formation in each program type: of the 225 students assigned to treatment in academically focused programs, 75.1 percent connected with their mentors by the time of the follow up survey; in relationship-only programs, 75.6 percent of protégés reported feeling close to their mentors. Columns (3) and (4) present the 2SLS treatment-on-treated estimates for the constrained and unconstrained specifications, respectively, using an expanded instrument set created by interacting treatment assignment with program type. Column (3) uses one endogenous regressor and thus is overidentified. Column (4) has two endogenous regressors (relationship closeness in each of the program types) and thus is just-identified. We find that academically focused programs do not yield detectably different estimates of the effect of having a close SBM relationship. Following Angrist (1991), the overidentification test statistic in column (3) indicates that the 2SLS estimates in column (4) are not significantly different (all p-values exceed .10), and thus we find no evidence of a causal link between assigned treatment status and the outcomes other than through the relationship formed between mentor and protégé.

\section{Relationship Closeness vs. Relationship Length and Status}

In Table 6, we first reproduce the apparent benefits of match intactness, originally reported by Grossman et al. (2012), for each outcome measure. When we interact the relationship closeness indicator with match status, however, we find that only close matches had an impact. Protégés in intact matches who were not close to their mentors fared no better than they would have without mentors. Notably, protégés who were rematched and had close relationships with their new mentors were not negatively affected. Indeed, there is evidence that rematched students in close relationships were doing better than their control peers in some measures.

In Table 7, we first provide analyses that include indicators of match duration but not closeness and 
find that longer matches apparently yielded greater benefits. Once we control for match closeness by interacting the closeness indicator with match duration, we estimate that only close relationships had benefits. If a match was long but not close, it does not appear to have improved academic outcomes. Close matches, regardless of duration, are associated with positive and statistically significant changes in academic outcomes.

Because Tables 6 and 7 report the results of OLS regressions, we take steps to address possible omitted variable bias even though the results of the previous section suggest such steps are unnecessary. Although we do not have adequate instruments to use 2SLS, specifications that include the teacher relationship variable to control for variation in student relationship ability produce estimates similar to those reported in the tables.

\section{Facilitating Close Relationships in SBM}

Table 8 reports evidence on program, mentor, and youth characteristics associated with close mentorprotégé relationships, presenting odds ratios from logistic regression with data on all students assigned to treatment. As in column (1), protégés less frequently reported close connection with their mentors in programs where all pairs met at the same time and location and in programs where pairs met only once or twice a month. Program type, academically focused or relationship-only, did not affect closeness. Column (2) further investigates the negative association of all matches meeting at the same time and location and finds that the largegroup setting appeared to impair relationship formation whether or not the mentor was a high school student.

Protégés were less likely to feel close to college student mentors than to adult volunteers, but more likely to feel close to high school student mentors. Same-race and same-gender matches were not more likely to be close. As column (3) shows, protégés were more likely to feel close to mentors who showed up when they were supposed to, as rated by the protégés, especially when the program's meetings were infrequent. Of course, the possibility of endogeneity bias does exist, as a mentor may not have shown up if the pair was not feeling particularly close. Mentors who received more training before and during their mentoring assignments were more likely to have close relationships with their protégés. Older students were less likely to report feeling close to their mentors, as were students who reported experiencing more stress in the prior six months.

\section{DISCUSSION}

This study finds evidence that unless a mentorship pair formed a relationship that the protégé would 
rate as "somewhat close" or better, BBBSA SBM program participation had no discernable effect on a student's end-of-school-year academic outcomes. We thus posit that this relationship is the "active ingredient" of mentoring in the school setting. This conclusion is very much in line with much of the theoretical perspective on mentoring (Ferguson \& Snipes, 1994; Rhodes, 2005) and suggests that SBM as implemented within program models such as that of BBBSA does not work as a tutoring program or by providing a context for specific training that is beneficial independent of relationship strength or duration, as Cavell and Elledge (2014) suggest can be the case in programs with different structures. We also find that SBM programs that focused more heavily on academic activity had no larger academic effects than those where mentors engaged primarily in social activities.

Much of the field's thinking about mentoring developed from community-based mentoring programs. That common wisdom says it takes time, often months, for trust to be built so that the match can affect the life of a child (Grossman \& Rhodes, 2002). The present study provides insight into the nature and function of mentoring relationships in the school setting. We find that a majority of protégés reported fairly close relationships, even if they had been matched only for a month or two, and that such relationships accounted for positive impacts on academic outcomes. This finding is consistent with research on teacher-student relationships, which has also identified the importance of closeness for academic achievement (e.g., MaldonadoCarreno \& Votruba-Drzal, 2011). Perhaps the school setting encourages children to trust unrelated adults more quickly, or children may have lower thresholds for close relationships with "school adults" than with "community adults.” The fact that relationships between protégés and mentors in the BBBSA SBM program seem to gel quickly may be why in their analyses with these same data Grossman et al. (2012) found little association between months of mentoring and academic impacts. As noted, we also find evidence of a threshold of closeness, in which "somewhat" and "very" close relationships produced statistically similar impacts. This finding suggests that SBM training and support might focus on facilitating amicable but not necessarily deep relationships between mentor and protégé. While the analyses presented here employ a direct, single-item report of the degree of emotional closeness the protégé feels towards the mentor, other studies have found that this report aligns with other measures of relationship quality (Herrera et al., 2007; Pryce \& Keller, 2012). 
Future research can produce a richer understanding of the timing, depth, and function of SBM relationships by including additional measures of child- and mentor- perceptions of relationship closeness.

Program staff and empirical researchers alike often worry that the children able to form the best relationships are those who would have normally done well anyway — in school or life — because of hard-tomeasure characteristics such as persistence or a child's ability to get along with adults. But we find little evidence for this type of sorting among protégés with close relationships. If this type of process were occurring, we would see large differences between the 2SLS impact estimates (which account for this potential selfselection) and the estimates obtained from the simpler OLS regressions. From a technical point of view, this finding is good news because it means we can control for closeness directly, without having to worry that this indicator is correlated with the error term. But from a programmatic point of view the finding is even more important, as it suggests that BBBSA SBM programs can be similarly helpful to all types of students.

Our estimated treatment-on-treated effect sizes, ranging from 0.13 to 0.18 standard deviations, compare favorably to the changes displayed by control students over the course of the academic year, who exhibited small increases in overall academic performance and quality of work of 0.07 and 0.02 standard deviations, respectively, and decreases in completion of work and scholastic efficacy beliefs of -..04 and -.05 standard deviations. Moreover, the estimated effects of a close relationship with a mentor assigned through the BBBSA SBM program are comparable to the size of the impacts of more expensive school-based interventions; in Project STAR, for example, the academic achievement impacts of reduced class sizes were an estimated 0.1 to 0.2 standard deviations (Krueger, 1999). Similarly, a meta-analysis of after-school programs reported average effect sizes ranging from 0.05 standard deviations on reading to 0.17 on math skills (Lauer et al., 2006).

The present findings shed light on the perplexing rematch result reported by Grossman et al. (2012) in analyses of the same data. That study found that rematched protégés performed less well than students who never had a mentor. The authors hypothesized that perhaps the relationships had not gelled sufficiently. That explanation does not seem plausible now that we know how quickly SBM relationships can click, at least from the protégé's perspective. Indeed, once we control for the quality of the matches, we see that while close, intact matches had large and statistically significant estimated impacts on academic outcomes, the estimated impacts 
for rematched students in close relationships were also positive and fairly similar to those of the students who remained in their original mentoring relationships. The negative effects appear to be centered among the rematched protégés who did not feel close to their new mentors (though the subsamples are small and the standard errors on these coefficients are large). These findings suggest that program staff should be attentive to the emotional tenor of the relationship in the new match and not rush to rematch if the pair is unlikely to gel.

Similarly, this paper informs the "length plus strength" proposition that grew out of earlier work on the BBBSA CBM program, in which effects of mentoring were observed to increase over time after a trusting relationship had apparently formed (Grossman \& Rhodes, 2002). We find that only close relationships have impacts and that match length is not so important in the SBM administered by BBBSA. Relatively long and close relationships led to improvements in academic outcomes, but so did shorter relationships that were close. More specifically, positive impacts on the completion and quality of the student's homework appeared to happen rather quickly, as long as the relationship was close, while improvements in the teacher's overall assessment of the student's performance and in the student's assessment of his or her own scholastic competence did appear to grow larger over time in close relationships. More research involving large numbers of students can provide more insight into the roles of match length and match status.

The analyses carried out in this study suggest that the BBBSA SBM program (and potentially others with similar characteristics) can make close relationships more likely by incorporating several practices: not having all pairs meet in the same area at the same time; giving mentors some structured activities to do with their protégés; asking mentors to come at least three times a month; and, providing BBBSA staff support to mentors. It might be a challenge for underfunded schools to provide adequate mentoring space, especially if mentors and protégés need multiple locations to meet on their own: schools might have to pay custodians more to clean the spaces after hours, for example. They may be able to keep costs low by encouraging pairs to meet individually during the school day but should be mindful of the potential harm of missing class time (Schwartz et al., 2012). Future research building on the empirical methods and findings of our study can assist administrators by exploring how variables known to influence the effectiveness of SBM, such as meeting time or the quality of the parent relationship (Schwartz et al., 2011), might moderate both the impact of a close mentor- 
protégé relationship on outcomes and the likelihood that such a relationship forms at all.

Although we did not find that academically focused mentoring led to better academic outcomes if the mentoring relationship was not close, it still may be justified to center well-designed volunteer programs on academic help. The mentors studied here were given no instruction in tutoring, nor did they have a structured curriculum to follow. The evidence from this study should therefore not be used to conclude that volunteer tutoring programs are ineffective or that incorporating an academic focus into mentoring programs is without potential benefit. At the same time, greater attention to the importance of closeness could improve the effectiveness of tutoring programs and other school programs. Program designers would do well to incorporate practices that make it easier for staff members and volunteers to cultivate close relationships with the young participants and thereby potentially strengthen program effects.

This study presents an empirical framework to investigate rigorously the mechanisms by which a mentoring program may improve academic outcomes. Given that we find the mentor-protégé relationship to be the core element of mentoring, we believe that any analysis of experimental data on mentoring programs should consider the partial compliance model used in this paper. Although instrumental variables and other nonexperimental techniques may not produce results as convincing as evidence from randomized control trials, in the end it is not possible to randomly assign close relationships. Statistical techniques can appropriately adjust for the presence or absence of closeness. Building on the results of this study, future experiments can include designs created to refine our understanding of the mechanism behind mentoring effectiveness, with randomly selected mentoring matches or programs incorporating more relationship-building activities.

Many schools are struggling to meet the standards set by the No Child Left Behind Act of 2001, and the future holds even more mandates as states implement the Common Core Standards. Under binding budget constraints, volunteer labor will be increasingly attractive. We find that a SBM program that aims to provide students with supportive relationships can improve academic outcomes. Not every volunteer can be a good tutor, but many of them could help students academically by being a caring presence. 


\section{REFERENCES}

Angrist, J. D. (1991). Grouped-data estimation and testing in simple labor-supply models. Journal of Econometrics, 47, 243-66.

Angrist, J. D., Imbens, G. W., \& Rubin, D. B. (1996). Identification of causal effects using instrumental variables. Journal of the American Statistical Association, 91, 444-455.

Benjamini, Y., \& Hochberg, Y. (1995). Controlling for the false discovery rate: A practical and powerful approach to multiple testing. Journal of the Royal Statistical Society, Series B, 57, 289-300.

Bernstein, L., Dun Rappaport, C., Olsho, L., Hunt, D., \& Levin, M. (2009). Impact evaluation of the U.S. Department of Education's Student Mentoring Program (NCEE 2009-4047). Washington, DC: National Center for Education Evaluation and Regional Assistance, Institute of Education Sciences, U.S. Department of Education.

Big Brothers Big Sisters of America. (2013a). Our programs get things started. Retrieved from: http:// www.bbbs.org/site/c.9iILI3NGKhK6F/b.5968193/k.5031/Our_programs_get_things_started.htm.

Big Brothers Big Sisters of America. (2013b). School-based programs. Retrieved from: http:// www.bbbs.org/site/c.9iILI3NGKhK6F/b.5961387/k.6048/SchoolBased_Programs.htm.

Big Brothers Big Sisters of America. (2013c). We are here to start something. Retrieved from: http:// www.bbbs.org/site/c.9iILI3NGKhK6F/b.5962351/k.42EB/We_are_here_to_start_something.htm.

Bloom, H. (1984). Accounting for no-shows in experimental evaluation designs. Evaluation Review, 8, 225-246.

Cavell, T. A., \& Elledge, L.C. (2014). Mentoring and prevention science. In D.L. DuBois \& M.J. Karcher (Eds.), Handbook of youth mentoring ( $2^{\text {nd }}$ ed., pp. 29-42). Thousand Oaks, CA: Sage Publications.

DuBois, D. L., \& Karcher, M. J. (Eds.). (2014). Handbook of youth mentoring ( $2^{\text {nd }}$ ed.). Thousand Oaks, CA: Sage Publications.

DuBois, D. L., \& Neville, H. A. (1997). Youth mentoring: Investigation of relationship characteristics and perceived benefits. Journal of Community Psychology, 25, 227-234.

DuBois, D. L., Portillo, N., Rhodes, J. E., Silverthorn, N., \& Valentine, J. C. (2011). How effective are mentoring programs for youth? A systematic assessment of the evidence. Psychological Science in the Public Interest, 12, 57-91.

Ferguson, R. F., \& Snipes, J. (1994). Outcomes of mentoring: Healthy identities for youth. Reclaiming Children and Youth, 3, 19-22. 
Grossman, J. B., Chan, C. S., Schwartz, S. E., \& Rhodes, J. E. (2012). The test of time in school-based mentoring: The role of relationship duration and re-matching on academic outcomes. American Journal of Community Psychology, 49, 43-54.

Grossman, J. B., \& Rhodes, J. E. (2002). The test of time: Predictors and effects of duration in youth mentoring relationships. American Journal of Community Psychology, 30, 199-219.

Harter, S. (1985). Manual for the Self Perception Profile for Children. Denver, CO: University of Denver.

Harter, S. (1990). Identity and self development. In S. Feldman and G. Elliott (Eds.), At the Threshold: The Developing Adolescent. Cambridge, MA: Harvard University Press.

Hausman, J. A. (1978). Specification tests in econometrics. Econometrica, 46, 1251-1271.

Herrera, C. (2004). School-based mentoring: A closer look. Philadelphia, PA: Public/Private Ventures.

Herrera, C., DuBois, D. L., \& Grossman, J. B. (2013). The role of risk: Mentoring experiences and outcomes for youth with varying risk profiles. New York, NY: Public/Private Ventures and MDRC.

Herrera, C., Grossman, J. B., Kauh, T. J., Feldman, A. F., \& McMaken, J. (2007). Making a difference in schools: The Big Brothers Big Sisters school-based mentoring impact study. Philadelphia, PA: Public/Private Ventures.

Herrera, C., Grossman, J. B., Kauh, T. J., \& McMaken, J. (2011). Mentoring in schools: An impact study of Big Brothers Big Sisters school-based mentoring. Child Development, 82, 346-361.

Imbens, G., \& Angrist, J. (1994). Identification and estimation of local average treatment effects. Econometrica, 62, 467-75.

Institute of Education Sciences. (2011). WWC Procedures and Standards Handbook (Version 2.1). Washington, DC: Institute of Education Sciences, U.S. Department of Education.

Karcher, M. J. (2003). The Hemingway: Measure of adolescent connectedness. Retrieved June 25, 2013, from http://www.adolescentconnectedness.com

Krueger, A. B. (1999). Experimental estimates of education production functions. Quarterly Journal of Economics, 114, 497-532.

Lauer, P. A., Akiba, M., Wilkerson, S. B., Apthorp, H. S., Snow, D., \& Martin-Glenn, M. L. (2006). Outof-school-time programs: A meta-analysis of effects for at-risk students. Review of Educational Research, 76, 275-313. 
Maldonado-Carreno, C., \& Votruba-Drzal, E. (2011). Teacher-child relationships and the development of academic and behavioral skills during elementary school: A within- and between-child analysis. Child Development, 82, 601-616.

MENTOR. (2006). Mentoring in America 2005: A snapshot of the current state of mentoring. Retrieved from http://www.mentoring.org/downloads/mentoring_333.pdf.

Parra, G. R., DuBois, D. L., Neville, H. A., Pugh-Lilly, A. O., \& Povinelli, N. (2002). Mentoring relationships for youth: Investigation of a process-oriented model. Journal of Community Psychology, 30, 367-388.

Pierce K. M., Bolt D. M., \& Vandell D. (2010). Specific features of after-school program quality: Associations with children's functioning in middle childhood. American Journal of Community Psychology, $45,381-393$.

Pierce, K. M., Hamm, J. V., \& Vandell, D. L. (1999). Experiences in after-school programs and children's adjustment in first-grade classrooms. Child Development, 70, 756-767.

Pryce, J., \& Keller, T. E. (2012). An investigation of volunteer-student relationship trajectories within school-based youth mentoring programs. Journal of Community Psychology, 40, 228-248.

Rhodes, J. E. (2005). A model of youth mentoring. In D.L. DuBois, \& M.J. Karcher (Eds.), Handbook of youth mentoring (pp. 30-43). Thousand Oaks, CA: Sage Publications.

Schwartz, S., Rhodes, J., Chan, C. \& Herrera, C. (2011). The impact of school-based mentoring on youth with different relational profiles. Developmental Psychology, 47, 450-462.

Schwartz, S., Rhodes, J., \& Herrera, C. (2012). The influence of meeting time on academic outcomes in school-based mentoring." Children and Youth Services Review, 34, 2319-2326.

Thomson, N. R., \& Zand, D. H. (2010). Mentees' perceptions of their interpersonal relationships: the role of the mentor-youth bond. Youth \& Society, 41, 434-445.

Wheeler, M. E., Keller, T. E., \& DuBois, D. L. (2010). Review of three recent randomized trials of school-based mentoring: Making sense of mixed findings. SRCD Social Policy Report, 24.

Zand, D., Thomson, N. R., Cervantes, R., Espiritu, R., Klagholz, D., LaBlanc, L., \& Taylor, A. (2009). The mentor-youth alliance: the role of mentoring relationships in promoting youth competence. Journal of Adolescence, 32, 1-17. 
FIGURE 1. PROPORTION OF MATCHES WITH HIGH PROTÉGÉ CLOSENESS RATING, BY DURATION IN MONTHS

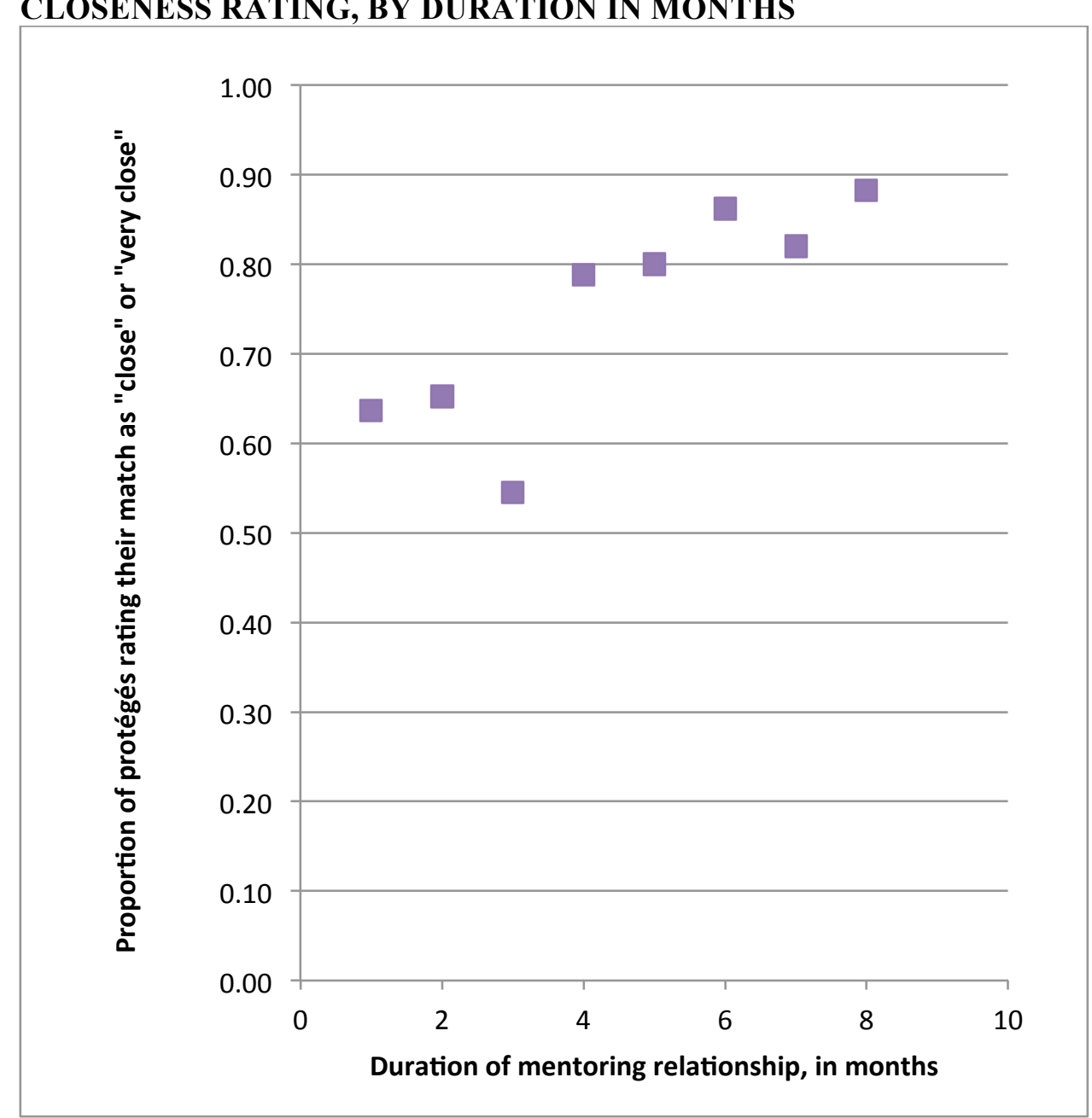


TABLE 1. STUDENT CHARACTERISTICS AT BASELINE

\begin{tabular}{lllllll}
\hline & \multicolumn{2}{l}{ Control } & \multicolumn{2}{c}{ Treatment } & \multicolumn{2}{c}{$\begin{array}{l}\text { Difference } \\
\text { (Control-Treatment) }\end{array}$} \\
\hline & Mean & $\begin{array}{l}\text { Standard } \\
\text { deviation }\end{array}$ & Mean & $\begin{array}{l}\text { Standard } \\
\text { deviation }\end{array}$ & Mean & $\begin{array}{l}\text { Standard } \\
\text { error }\end{array}$ \\
\hline Age & 11.22 & 1.66 & 11.24 & 1.67 & -.02 & .099 \\
African-American/Hispanic (proportion) & 0.61 & 0.49 & 0.64 & 0.48 & -.04 & .029 \\
Female (proportion) & 0.54 & 0.50 & 0.54 & 0.50 & .00 & .030 \\
Free/reduced-price lunch (proportion) & 0.69 & 0.43 & 0.69 & 0.43 & -.00 & .025 \\
Number of stressful life events & 4.41 & 2.54 & 4.64 & 2.62 & -.22 & .153 \\
Teacher-rated outcome measures: & & & & & & \\
$\quad$ Overall academic performance & 2.47 & 1.09 & 2.56 & 1.10 & -.08 & .070 \\
$\quad$ Quality of schoolwork & 2.82 & 0.91 & 2.84 & 0.94 & -.02 & .058 \\
$\quad$ Completion of schoolwork & 2.96 & 0.99 & 3.00 & 1.06 & -.04 & .065 \\
Student-reported outcome measure: & & & & & & \\
$\quad$ Scholastic efficacy beliefs & 2.75 & 0.64 & 2.80 & 0.62 & -.05 & .038 \\
\hline Sample size & 574 & & 565 & & & \\
\hline
\end{tabular}

NOTES: See text for description of outcome measures. A two-tailed t-test was applied to differences between the groups. No differences were statistically significant at a 10 percent level.

TABLE 2. PROGRAM FEATURES

\begin{tabular}{lcc}
\hline Treatment & Mean & Standard Deviation \\
\hline Academically focused program+ + & 0.49 \\
All pairs meeting at same time and location+ & 0.40 & 0.50 \\
Some structured time+ + & 0.44 & 0.46 \\
Infrequent meetings + & 0.71 & 0.33 \\
Volunteer recognition++ & 0.13 & 1.49 \\
High school student mentor+ & 2.63 & 0.50 \\
College student mentor+ & 0.49 & 0.37 \\
Same gender mentor as student+ & 0.16 & 0.39 \\
Same race mentor as student+ + & 0.80 & 0.50 \\
"Mentor shows up when he/she is supposed to"+++ & 0.49 & 0.94 \\
Amount of individual mentor training++++ & 3.33 & 1.45 \\
\hline Sample size & 3.10 & \\
\hline
\end{tabular}

NOTES: + The mean of this variable represents the proportion of students assigned to treatment who were mentored under the specified condition.

++ This variable records the number of ways programs recognized volunteers' efforts.

+++ The mean of this variable represents the average rating by the student on a scale from $1=$ "not at all true" to 5 = "very true."

++++ This variable is the sum of mentor training before and after match using the following categorical scale: $1=$ less than 30 minutes, $2=30$ minutes to less than one hour, $3=$ one hour to less than two hours, $4=$ two hours to less than four hours, $5=$ four hours or more. 
TABLE 3. ESTIMATED IMPACT OF A CLOSE RELATIONSHIP ON ACADEMIC OUTCOMES

\begin{tabular}{cccc}
$(1)$ & $(2)$ & $(3)$ & $(4)$ \\
ITT & TOT & $\begin{array}{l}\text { TOT controlling } \\
\text { for relationship } \\
\text { ability }\end{array}$ & 2SLS \\
\hline
\end{tabular}

Overall academic performance (sample size $=945$ )

\begin{tabular}{lcccc}
\hline Assigned to treatment & $\begin{array}{c}0.12^{* *} \\
(0.05)\end{array}$ & & & \\
& & $0.14^{* * *}$ & $0.14^{* * *}$ & $0.14^{* *}$ \\
Received treatment & & $(0.05)$ & $(0.05)$ & $(0.06)$ \\
(had a close relationship) & .534 & .535 & .536 & .535 \\
\hline$R^{2}$ & & \\
\hline
\end{tabular}

Quality of work (sample size $=953$ )

\begin{tabular}{lcccc}
\hline Assigned to treatment & $\begin{array}{c}0.12^{* * *} \\
(0.04)\end{array}$ & & & \\
& & $0.14^{* * *}$ & $0.14^{* * *}$ & $0.15^{* * * *}$ \\
Received treatment & & $(0.04)$ & $(0.04)$ & $(0.05)$ \\
(had a close relationship) & .478 & .480 & .483 & .480 \\
\hline$R^{2}$ & & & \\
\hline
\end{tabular}

Completion of schoolwork (sample size $=953$ )

\begin{tabular}{lcccc}
\hline Assigned to treatment & $\begin{array}{c}0.15^{* * *} \\
(0.05)\end{array}$ & & & \\
& & $0.17^{* * *}$ & $0.17^{* * *}$ & $0.18^{* * *}$ \\
Received treatment & & $(0.05)$ & $(0.05)$ & $(0.06)$ \\
(had a close relationship) & & .386 & .390 & .386 \\
\hline$R^{2}$ & .385 & & \\
\hline
\end{tabular}

Scholastic efficacy beliefs (sample size $=1067$ )

\begin{tabular}{lcccc}
\hline Assigned to treatment & $\begin{array}{c}0.07^{* *} \\
(0.03)\end{array}$ & & & \\
Received treatment & & $0.08^{* *}$ & $0.07^{* *}$ & $0.08^{* *}$ \\
(had a close relationship) & & $(0.03)$ & $(0.03)$ & $(0.04)$ \\
\hline$R^{2}$ & .268 & .269 & .275 & .269 \\
\hline
\end{tabular}

NOTES: This table reports impact coefficients representing the estimated change in the outcome measure associated with (assignment to) treatment. Column (1) presents the intention-to-treat (ITT) coefficients obtained from estimating equation (1). Column (2) presents the treatment-on-treated (TOT) coefficients obtained from estimating equation (2). Column (3) presents the treatment-on-treated (TOT) coefficients estimated while controlling for the quality of the protégé's relationship with his or her teacher. Column (4) presents the two-stage least squares (2SLS) estimates using assigned treatment status as an instrument for having a close relationship with a mentor. The baseline academic measure is included as a covariate in all specifications. Standard errors are shown in parentheses. Statistical significance levels are indicated as: $*=10$ percent; $* *=5$ percent; and $* * *=1$ percent. 
TABLE 4. ESTIMATED IMPACT OF MENTORING, WITH AND WITHOUT A CLOSE RELATIONSHIP

\begin{tabular}{lcccc}
\hline & $\begin{array}{c}\text { Overall } \\
\text { academic } \\
\text { performance }\end{array}$ & $\begin{array}{c}\text { Quality } \\
\text { of } \\
\text { work }\end{array}$ & $\begin{array}{c}\text { Completion } \\
\text { of school- } \\
\text { work }\end{array}$ & $\begin{array}{c}\text { Scholastic } \\
\text { efficacy } \\
\text { beliefs }\end{array}$ \\
\hline $\begin{array}{l}\text { Received treatment } \\
\text { (had a close relationship) }\end{array}$ & $\begin{array}{c}0.14^{* * *} \\
(0.05)\end{array}$ & $\begin{array}{c}0.14^{* * *} \\
(0.05)\end{array}$ & $\begin{array}{c}0.18^{* * *} \\
(0.06)\end{array}$ & $\begin{array}{c}0.07^{* *} \\
(0.03)\end{array}$ \\
$\begin{array}{l}\text { Assigned a mentor but did not receive treatment } \\
\text { (did not have a close relationship) }\end{array}$ & 0.03 & -0.04 & 0.05 & -0.02 \\
Sample size & $(0.09)$ & $(0.08)$ & $(0.08)$ & $(0.06)$ \\
$R^{2}$ & 945 & 953 & 953 & 1067 \\
\hline
\end{tabular}

NOTES: This table reports impact coefficients representing the estimated effect on the outcome measure in each condition relative to controls. The baseline academic measure is included as a covariate in all specifications. Standard errors are shown in parentheses. Statistical significance levels are indicated as: * $=10$ percent; $* *=5$ percent; and $* * *=1$ percent. 
TABLE 5. ESTIMATED IMPACT ON ACADEMIC OUTCOMES, BY PROGRAM TYPE

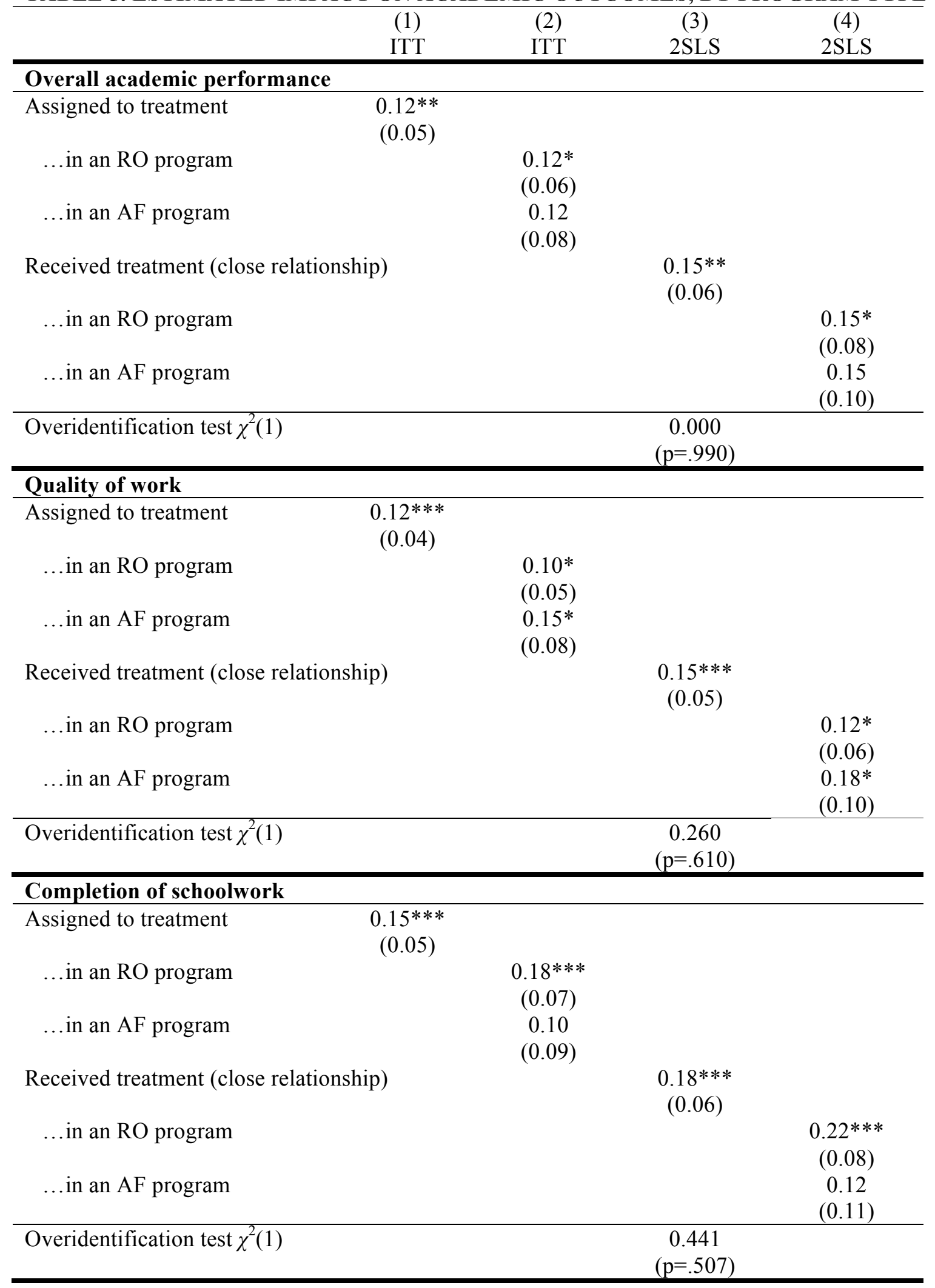


TABLE 5 (continued)

\begin{tabular}{|c|c|c|c|}
\hline \multicolumn{4}{|l|}{ Scholastic efficacy beliefs } \\
\hline Assigned to treatment & & & \\
\hline ...in an $\mathrm{RO}$ program & $\begin{array}{c}0.03 \\
(0.04)\end{array}$ & & \\
\hline ...in an AF program & $\begin{array}{l}0.14^{* *} \\
(0.06)\end{array}$ & & \\
\hline Received treatment (close relationship) & & $\begin{array}{l}0.09 * * \\
(0.04)\end{array}$ & \\
\hline ...in an $\mathrm{RO}$ program & & & $\begin{array}{c}0.04 \\
(0.05)\end{array}$ \\
\hline ... in an AF program & & & $\begin{array}{l}0.17^{* *} \\
(0.07)\end{array}$ \\
\hline Overidentification test $\chi^{2}(1)$ & & $\begin{array}{c}2.39 \\
(p=.122)\end{array}$ & \\
\hline
\end{tabular}

NOTES: This table reports impact coefficients representing the estimated change in the outcome measure associated with (assignment to) treatment. $\mathrm{AF}=$ academically focused, $\mathrm{RO}=$ relationship-only, $\mathrm{ITT}=$ intention-to-treat, and 2SLS = two-stage least squares. Columns (1) and (3) constrain the impacts across AF and RO sites to be the same, whereas columns (2) and (4) allow them to differ. The baseline academic measure is included as a covariate in all specifications. Standard errors are shown in parentheses. Statistical significance levels are indicated as: $*=10$ percent; $* *=5$ percent; and $* * *=1$ percent. 
TABLE 6. ESTIMATED IMPACT OF MATCH STATUS, CONTROLLING FOR RELATIONSHIP CLOSENESS

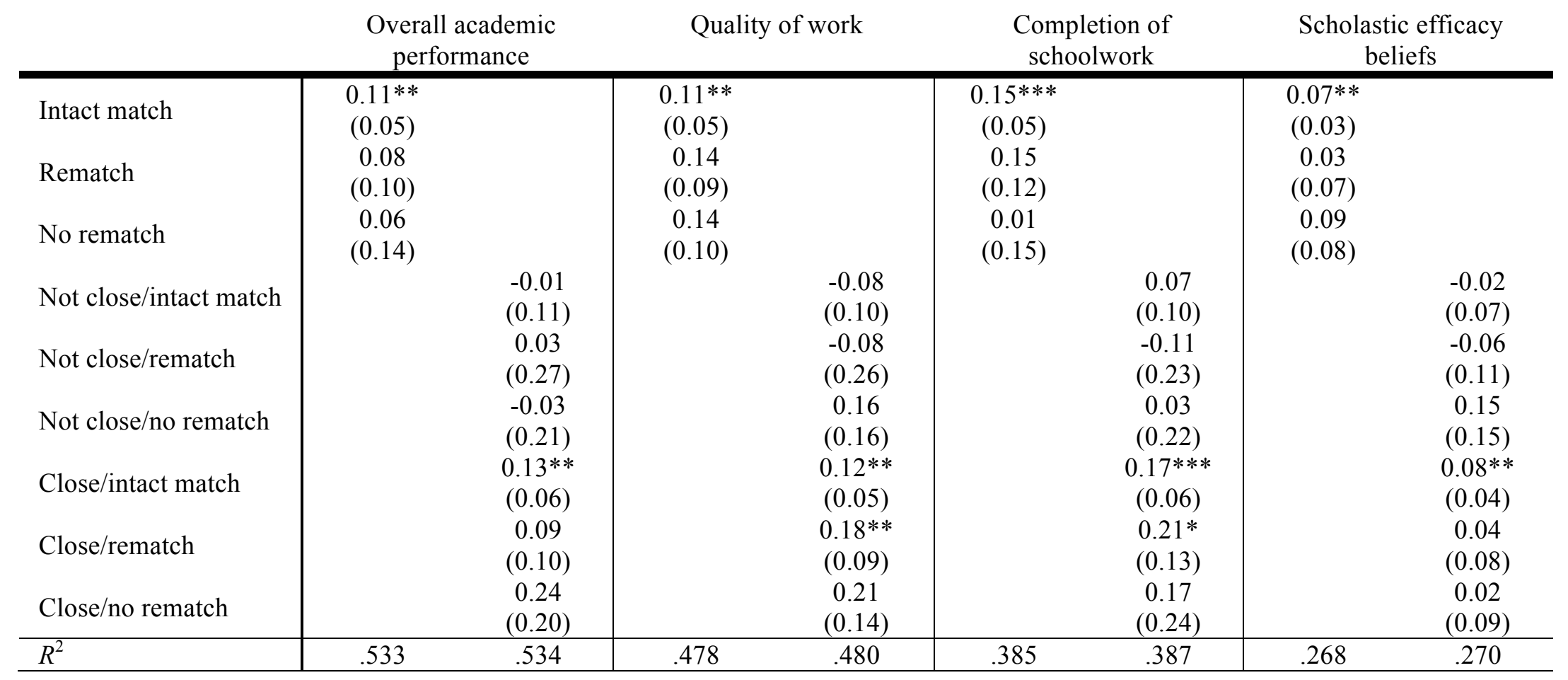

NOTES: This table reports impact coefficients representing estimated changes in the outcome measures. Standard errors are shown in parentheses. The baseline academic measure is included as a covariate in all specifications. Statistical significance levels are indicated as: $*=10$ percent; $* *=$ 5 percent; and $* * *=1$ percent. 
TABLE 7. ESTIMATED IMPACT OF MATCH LENGTH, CONTROLLING FOR RELATIONSHIP CLOSENESS

\begin{tabular}{|c|c|c|c|c|c|}
\hline & $\begin{array}{l}\text { Overall academic } \\
\text { performance }\end{array}$ & Quality of work & $\begin{array}{l}\text { Completion of } \\
\text { schoolwork }\end{array}$ & \multicolumn{2}{|c|}{$\begin{array}{c}\text { Scholastic efficacy } \\
\text { beliefs }\end{array}$} \\
\hline Short & $\begin{array}{c}0.00 \\
(0.09)\end{array}$ & $\begin{array}{c}0.06 \\
(0.08)\end{array}$ & $\begin{array}{c}0.13 \\
(0.11)\end{array}$ & $\begin{array}{c}0.04 \\
(0.06)\end{array}$ & \\
\hline Medium & $\begin{array}{l}0.13 * \\
(0.07)\end{array}$ & $\begin{array}{c}0.13 * * \\
(0.06)\end{array}$ & $\begin{array}{l}0.14^{*} \\
(0.08)\end{array}$ & $\begin{array}{c}0.06 \\
(0.05)\end{array}$ & \\
\hline Long & $\begin{array}{l}0.14^{* *} \\
(0.06)\end{array}$ & $\begin{array}{l}0.13^{* *} \\
(0.05)\end{array}$ & $\begin{array}{c}0.16^{* * * *} \\
(0.06)\end{array}$ & $\begin{array}{r}0.09^{* *} \\
(0.04)\end{array}$ & \\
\hline Not close/short & $\begin{array}{l}-0.08 \\
(0.19)\end{array}$ & $\begin{array}{l}-0.10 \\
(0.17)\end{array}$ & $\begin{array}{l}-0.03 \\
(0.17)\end{array}$ & & $\begin{array}{c}0.03 \\
(0.10)\end{array}$ \\
\hline Not close/medium & $\begin{array}{c}0.14 \\
(0.13)\end{array}$ & $\begin{array}{c}0.04 \\
(0.13)\end{array}$ & $\begin{array}{c}0.14 \\
(0.16)\end{array}$ & & $\begin{array}{c}0.00 \\
(0.10)\end{array}$ \\
\hline Not close/long & $\begin{array}{c}0.01 \\
(0.14)\end{array}$ & $\begin{array}{l}-0.00 \\
(0.12)\end{array}$ & $\begin{array}{c}0.04 \\
(0.10)\end{array}$ & & $\begin{array}{l}-0.05 \\
(0.09)\end{array}$ \\
\hline Close/short & $\begin{array}{l}0.06 \\
(0.10)\end{array}$ & $\begin{array}{l}0.15^{*} \\
(0.09)\end{array}$ & $\begin{array}{l}0.26^{*} \\
(0.14)\end{array}$ & & $\begin{array}{c}0.04 \\
(0.08)\end{array}$ \\
\hline Close/medium & $\begin{array}{l}0.11^{*} \\
(0.07)\end{array}$ & $\begin{array}{l}0.12^{*} \\
(0.07)\end{array}$ & $\begin{array}{l}0.15^{*} \\
(0.09)\end{array}$ & & $\begin{array}{c}0.08 \\
(0.05)\end{array}$ \\
\hline Close/long & $\begin{array}{c}0.19 * * * \\
(0.08)\end{array}$ & $\begin{array}{c}0.15^{* * *} \\
(0.06)\end{array}$ & $\begin{array}{c}0.18^{* * * *} \\
(0.06)\end{array}$ & & $\begin{array}{r}0.10^{* *} \\
(0.04)\end{array}$ \\
\hline$R^{2}$ & .537 & .481 & .387 & .269 & .270 \\
\hline
\end{tabular}

NOTES: This table reports impact coefficients representing estimated changes in the outcome measures. Short indicates match duration less than 12 weeks, medium between 12 and 24 weeks, and long more than 24 weeks. The baseline academic measure is included as a covariate in all specifications. Standard errors are shown in parentheses. Statistical significance levels are indicated as: $*=10$ percent; $* *=5$ percent; and $* * *=1$ percent. 
TABLE 8. PREDICTORS OF A CLOSE RELATIONSHIP (ODDS RATIOS)

\begin{tabular}{|c|c|c|c|}
\hline & $(1)$ & $(2)$ & (3) \\
\hline \multicolumn{4}{|l|}{ Program features } \\
\hline Academic focus & 0.69 & 0.70 & 0.24 \\
\hline & $(0.47)$ & $(0.46)$ & $(0.23)$ \\
\hline All matches meeting at same time and location & $\begin{array}{l}0.31 * * * \\
(0.13)\end{array}$ & & $\begin{array}{l}0.20 * * * \\
(0.12)\end{array}$ \\
\hline if high school student mentor & & $\begin{array}{l}0.24^{* * *} \\
(0.13)\end{array}$ & \\
\hline if not high school student mentor & & $\begin{array}{l}0.40 * * \\
(0.18)\end{array}$ & \\
\hline Some structured time & $\begin{array}{l}1.35 \\
(0.59)\end{array}$ & $\begin{array}{l}1.33 \\
(0.58)\end{array}$ & $\begin{array}{l}1.25 \\
(0.83)\end{array}$ \\
\hline Infrequent meetings & $\begin{array}{l}0.28^{* * *} \\
(0.13)\end{array}$ & $\begin{array}{l}0.29 * * * \\
(0.13)\end{array}$ & $\begin{array}{l}0.00 * * * \\
(0.00)\end{array}$ \\
\hline Volunteer recognition & $\begin{array}{l}1.01 \\
(0.15)\end{array}$ & $\begin{array}{l}1.04 \\
(0.16) \\
\end{array}$ & $\begin{array}{l}1.98^{*} \\
(0.70)\end{array}$ \\
\hline \multicolumn{4}{|l|}{ Mentor characteristics } \\
\hline High school student + & $\begin{array}{l}1.28 \\
(0.45)\end{array}$ & $\begin{array}{l}1.66 \\
(0.74)\end{array}$ & $\begin{array}{l}1.96 \\
(1.11)\end{array}$ \\
\hline College student + & $\begin{array}{l}0.27 * * * \\
(0.12)\end{array}$ & $\begin{array}{l}0.27 * * * \\
(0.12)\end{array}$ & $\begin{array}{l}0.47 \\
(0.46)\end{array}$ \\
\hline Same gender as student & $\begin{array}{l}0.88 \\
(0.37)\end{array}$ & $\begin{array}{l}0.88 \\
(0.37)\end{array}$ & $\begin{array}{l}1.82 \\
(1.24)\end{array}$ \\
\hline Same race as student & $\begin{array}{l}1.15 \\
(0.33)\end{array}$ & $\begin{array}{l}1.14 \\
(0.33)\end{array}$ & $\begin{array}{l}1.39 \\
(0.79)\end{array}$ \\
\hline Mentor shows up & & & $\begin{array}{l}1.80 * * * \\
(0.30)\end{array}$ \\
\hline Mentor shows up/infrequent program meetings & & & $\begin{array}{l}3.17 * * \\
(1.71)\end{array}$ \\
\hline Amount of training mentor received & & & $\begin{array}{l}1.34 * * * \\
(0.12)\end{array}$ \\
\hline \multicolumn{4}{|l|}{ Youth characteristics } \\
\hline Age & $\begin{array}{l}0.82^{* * *} \\
(0.05)\end{array}$ & $\begin{array}{l}0.82^{* * *} \\
(0.05)\end{array}$ & $\begin{array}{l}0.71 * * * \\
(0.09)\end{array}$ \\
\hline Female & $\begin{array}{l}1.56 \\
(0.44)\end{array}$ & $\begin{array}{l}1.57 \\
(0.45)\end{array}$ & $\begin{array}{l}1.04 \\
(0.42)\end{array}$ \\
\hline African-American/Hispanic & $\begin{array}{l}1.43 \\
(0.50)\end{array}$ & $\begin{array}{l}1.44 \\
(0.50)\end{array}$ & $\begin{array}{l}2.28 \\
(1.64)\end{array}$ \\
\hline Free/reduced-price lunch & $\begin{array}{l}0.93 \\
(0.26)\end{array}$ & $\begin{array}{l}0.91 \\
(0.26)\end{array}$ & $\begin{array}{l}1.28 \\
(0.51)\end{array}$ \\
\hline Stress & $\begin{array}{l}0.95 \\
(0.05)\end{array}$ & $\begin{array}{l}0.95 \\
(0.05)\end{array}$ & $\begin{array}{l}0.85 * * \\
(0.06)\end{array}$ \\
\hline Sample size & 474 & 474 & 271 \\
\hline
\end{tabular}

NOTES: Specifications include site fixed effects. +The reference group is adult mentors. Cluster-rot standard errors are shown in parentheses. Statistical significance levels are indicated as: $*=10$ perce $* *=5$ percent; and $* * *=1$ percent. 